\title{
PERBANDINGAN KUAT TEKAN MORTAR YANG MENGGUNAKAN AGREGAT HALUS SUNGAI MUSI SEKAYU DAN AGREGAT HALUS SUNGAI MUSI GANDUS PALEMBANG
}

\author{
Ligal Sebastian $^{1)}$, Diawarman ${ }^{2)}$ Sabarna Suhendra ${ }^{3)}$ \\ ${ }^{1), 2)}$ Dosen tetap YPTP pada Prodi. T. Sipil Universitas Palembang \\ ${ }^{3)}$ Mahasiswa Universitas Palembang
}

\begin{abstract}
Abstrak
Mortar merupakan bahan bangunan yang terbuat dari campuran air, bahan perekat (misalnya : lumpur, kapur, semen portland), dan agregat halus (misalnya : pasir alami, pecahan tembok, dan sebagainya) Konsistensi mortar ini nantinya akan berguna dalam menentukan kekuatan mortar yang menjadi spesi, plesteran dinding, batako dan sebagainya, sehingga diharapkan mortar yang menahan gaya tekan akibat beban yang bekerja padanya tidak hancur, maka pada penelitian ini dicoba membandingkan kuat tekan mortar yang menggunakan agregat halus sungai musi Sekayu dan agregat halus sungai musi gandus Palembang. Pada penelitian ini beda uji dicetak dengan menggunakan kubus baja ukuran $5 \mathrm{~cm} \times 5 \mathrm{~cm} \times 5 \mathrm{~cm}$, masing-masing umur mortar yaitu 7 hari, 14 hari, 21 hari dan 28 hari dengan pengujian kuat tekan mortar. Pada campuran mortar tersebut dibuat berfariasi yaitu dengan menggunakan 1 PC : 2 Pasir, 1 PC : 3 Pasir dan 1 PC : 4 Pasir. Dari hasil evaluasi uji kuat tekan yaitu pada mortar dengan campuran pasir sungai musi sekayu pada umur mortar 28 hari didapat kuat tekan mortar sebesar $50,00 \mathrm{~kg} / \mathrm{cm}^{2}, 56,00 \mathrm{~kg} / \mathrm{cm}^{2}$ dan $53,33 \mathrm{~kg} / \mathrm{cm}^{2}$ pada pada mortar dengan campuran pasir sungai musi gandus Palembang pada umur mortar 28 hari didapat kuat tekan mortar sebesar 31,80 $\mathrm{kg} / \mathrm{cm} 2,40,20 \mathrm{~kg} / \mathrm{cm}^{2}$ dan $38,73 \mathrm{~kg} / \mathrm{cm}^{2}$
\end{abstract}

Kata Kunci : Kuat tekan mortar, agregat halus sekayu, agregat halus gandus.

\section{PENDAHULUAN}

\subsection{Latar Belakang}

Mortar merupakan bahan bangunan yang terbuat dari campuran air, bahan perekat (misalnya : lumpur, kapur, semen portland), dan agregat halus (misalnya : pasir alami, pecahan tembok, dan sebagainya) [1], mortar mempunyai kuat tekan bervariasi sesuai dengan bahan penyusunya dan perbandingan antara bahan-bahan penyusunya [2]. Perbandingan semen, pasir dan air yang sesuai untuk mortar yang memiliki syarat adalah 1 : $2,75: 0,484$. sebagai bahan pengikat, mortar harus mempunyai konsistensi/kekentalan standar. Konsistensi mortar ini nantinya akan berguna dalam menentukan kekuatan mortar yang menjadi spesi, plesteran dinding, batako dan sebagainya, sehingga diharapkan mortar yang menahan gaya tekan akibat beban yang bekerja padanya tidak hancur. Agregat halus merupakan pasir alam hasil desintegrasi alami dari batu atau pasir yang dihasilkan oleh industri pemecah batu dengan ukuran butir terbesar 5,0 $\mathrm{mm}$ [3], maka pada penelitian ini dicoba menggunakan agregat halus sungai musi Sekayu dan agregat sungai musi gandus Palembang.

\subsection{Tujuan Penelitian}

Tujuan yang ingin dicapai dari penelitian ini adalah :

1. Mendapatkan kuat tekan optimum mortar dengan menggunakan agregat halus sungai musi Sekayu dan agregat sungai musi gandus Palembang.

2. Untuk menentukan besarnya kuat tekan mortar dengan umur tertentu yang menggunakan agregat halus sungai musi Sekayu dan agregat sungai musi gandus Palembang dengan contoh benda uji berbentuk kubus berukuran $5 \times 5 \times 5 \mathrm{~cm}$.

\subsection{Manfaat Penelitian}

Adapun manfaat yang diharapkan adalah sebagaiberikut :

1. Menghasilkan mortar yang mempunyai kuat tekan yang sama atau bahkan lebih tinggi dari mortar dengan menggunakan 
agregat halus sungai musi Sekayu dan agregat sungai musi gandus Palembang.

2. Memberikan alternatif menggunakan agregat halus sungai musi Sekayu dan agregat sungai musi gandus Palembang.

\subsection{Rumusan Masalah}

Rumusan masalah yang diambil dari penelitian ini adalah berapa besar kuat tekan optimum mortar dengan menggunakan agregat halus sungai musi Sekayu dan agregat sungai musi gandus Palembang pada umur 7 hari, 14 hari, 21 hari, dan 28 hari.

\subsection{Batasan Masalah}

Batasan masalah didalam penelitian ini penulis membatasi ruang lingkup pekerjaan pengujian - pengujian bahan material dan benda uji kuat tekan mortar di laboratorium.

\section{Tinjauan Pustaka}

\subsection{Mortar}

Mortar adalah campuran semen, pasir dan air yang memiliki persentase yang berbeda. Perbandingan semen, pasir dan air yang sesuai untuk mortar yang memenuhi syarat adalah $1: 2,75: 0,485$. Sebagai bahan pengikat, mortar harus mempunyai konsentrasi/kekentalan standar. Konsentrasi mortar ini nantinya akan berguna dalam menentukan kekuatan mortar yang menjadi spesi ataupun plesteran dinding sehingga diharapkan mortar yang menahan gaya tekan akibat beban yeng bekerja padanya tidak hancur (Teknologi Beton, 2008).

\subsection{Spesifikasi Mortar}

\subsubsection{Spesifikasi Proporsi dan Sifat} Mortar

Berdasarkan SNI 03-6882-2002, proporsi mortar di spesifikasikan dalam 4 tipe menurut kekuatan mortar dan ketentuan spesifikasi proporsi bahan yang terdiri dari bahan bersifat semen, agregat, dan air yang digunakan.

Tipe - tipe mortar adalah sebagai berikut :

1. Mortar tipe $M$ adalah mortar yang mempunyai kekuatan 17,2 $\mathrm{MPa}$, yang dibuat dengan menggunakan semen pasangan tipe $\mathrm{N}$ atau kapur semen dengan menambahkan semen portland dan kapur padam .
2. Mortar tipe $\mathrm{S}$ adalah mortar yang mempunyai kekuatan 12,5 $\mathrm{MPa}$, yang dibuat dengan menggunakan semen pasangan tipe $\mathrm{S}$ atau kapur semen dengan menambahkan semen portland dan kapur padam.

3. Mortar tipe $\mathrm{N}$ adalah mortar yang mempunyai kekuatan 5,2 MPa, yang dibuat dengan menggunakan semen pasangan tipe $\mathrm{N}$ atau kapur semen dengan menambahkan semen portland dan kapur padam.

4. Mortar tipe $\mathrm{O}$ adalah mortar yang mempunyai kekuatan 2,4 MPa, yang dibuat dengan menggunakan semen pasangan tipe $\mathrm{N}$ atau kapur semen dengan menambahkan semen portland dan kapur padam.

\subsubsection{Metode Pengujian}

a. Proporsi campuran bahan untuk benda uji Mortar yang dibuat dilaboratorium yang digunakan untuk menentukan sifat sifat menurut spesifikasi ini harus berisi bahan - bahan konstruksi dalam susunan campuran yang telah ditetapkan dalam spesifikasi proyek (SNI 03-6882-2002).

\section{b. Pencampuran Mortar}

Semua bahan bersifat semen dan agregat harus dicampur dengan sejumlah air secukupnya selama 3 - 5 menit dengan menggunakan alat pengaduk mekanis untuk menghasilkan mortar yang mudah dikerjakan. Pencampuran mortar dengan tangan diperbolehkan bila ada ijin dari pihak yang menentukan persyaratan dengan memberikan prosedur cara pencampuran yang dimaksud (SNI 03-6882-2002).

c. Pemeliharaan Kelecekan

Mortar yang telah mengeras harus diaduk kembali dengan tangan untuk mempertahankan kelecekannya, dan mortar yang telah mencapai lebih dari 2,5 jam sejak dicampur tidak boleh dipakai lagi (SNI 03-6882-2002).

\subsubsection{Kuat Tekan Mortar}

Untuk mengetahui perbandingan kuat tekan mortar dengan varian berbeda, perhitungan kuat tekan mortar menggunakan rumus :

$$
\begin{aligned}
\mathrm{f}^{\prime} \mathrm{c}= & \mathrm{P} / \mathrm{A} \\
\mathrm{f}^{\prime} \mathrm{c}= & \text { kuat tekan mortar, dalam } \\
& \mathrm{MPa}
\end{aligned}
$$


$P \quad=$ beban maksimum total, dalam $\mathrm{N}$

$A$ = luas dari permukaan yang dibebani, dalam $\mathrm{mm}^{2}$

\subsection{Material}

\subsubsection{Semen}

Material semen adalah material yang mempunyai sifat-sifat adhesif dan kohesif yang diperlukan untuk mengikat agregat-agregat menjadi suatu massa yang padat yang mempunyai kekuatan yang cukup.

Semen merupakan hasil industri dari paduan bahan baku : batu gamping/kapur sebagai bahan utama, yaitu bahan alam yang mengandung senyawa calcium oksida $(\mathrm{CaO})$ dan lempung/tanah liat yaitu bahan alam yang mengandung senyawa : silika oksida ( $\mathrm{SiO}$ ), alumunium oksida $\left(\mathrm{AL}_{2} \mathrm{O}_{3}\right)$, besi oksida $\left(\mathrm{Fe}_{2} \mathrm{O}_{3}\right)$ dan magnesium oksida $(\mathrm{MgO})$ atau bahan pengganti lainnya dengan hasil akhir berupa padatan bentuk bubuk (bulk), tanpa memendang proses pembuatannya, yang mengeras atau membatu pada pencampuran dengan air.

\subsubsection{Agregat}

Agregat halus merupakan pengisi yang berupa pasir. Agregat halus yang baik harus bebas bahan organik, lempung, partikel yang lebih kecil, atau bahanbahan lain yang dapat merusak campuran. Variasi ukuran dalam suatu campuran barus mempunyai gradasi yang baik.

Kekuatan mortar akan bertambah jika kandungan pori dalam mortar semakin kecil. Terjadi hubungan langsung antara kekuatan dengan kandungan pori dalam agregat. Semakin tinggi angka pori dalam agregat berarti semakin tinggi angka pori dalam mortar yang pada akhirnya akan menyebabkan turunnya kekuatan mortar.

Pasir merupakan agregat alami yang berasal dari letusan gunung berapi, sungai, dalam tanah dan pantai oleh karena itu pasir dapat digolongkan dalam tiga macam yaitu pasir galian, pasir laut dan pasir sungai.

\subsubsection{Air}

Air diperlukan pada pembuatan mortar untuk memicu proses kimiawi semen, membasahi agregat dan memberi kemudahan dalam pekerjaan mortar. Air yang dapat diminum umumnya dapat digunakan sabagai campuran mortar. Air yang mengandung senyawa-senyawa yang berbahaya, yang tercemar garam, minyak, gula, atau bahan kimia lainnya, bila dipakai dalam campuran mortar akan menurunkan kualitas mortar, bahkan dapat mengubah sifat mortar yang dihasilkan.

\section{METODOLOGI PENELITIAN}

\subsection{Bagan Alir Penelitian}

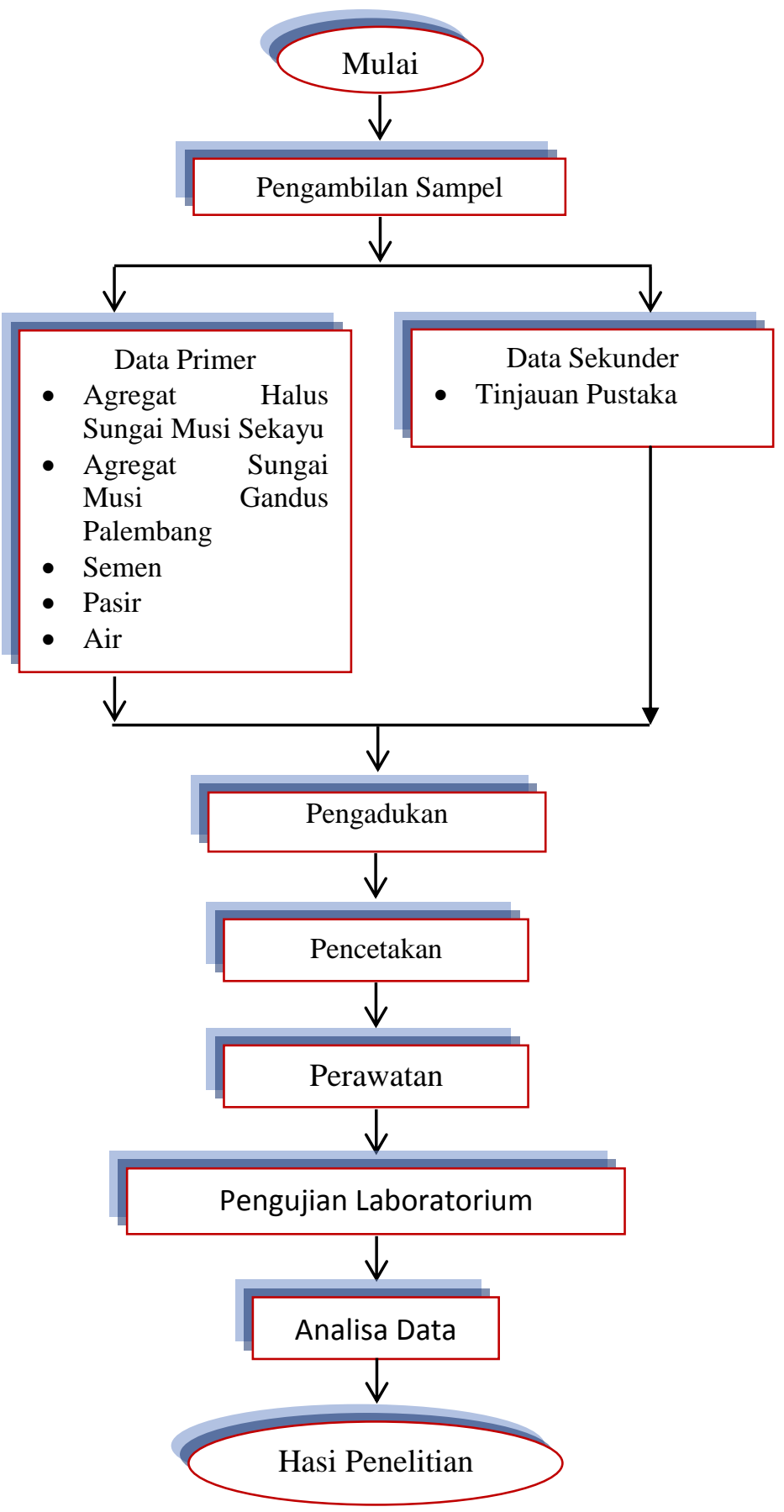

Gambar 1. Bagan Alir Penelitian 


\subsection{Tempat dan Waktu Penelitian}

$$
\text { Penelitian ini dilakukan di }
$$

Laboratorium Program Studi Teknik Sipil Politeknik Negeri Sriwijaya dengan waktu penelitian selama dua bulan.

\subsection{Jenis Penelitian dan Sumber Data}

Penelitian yang dilakukan adalah uji eksperimental, di mana kondisi dibuat dan diatur oleh peneliti dengan mengacu pada peraturan SNI (Standar Nasional Indonesia) serta literatur yang berkaitan.

\subsection{Alat dan Bahan Penelitian}

1. Timbangan dengan ketelitian 0,1 gram

2. Gelas ukur $1000 \mathrm{ml}$ Gelas ukur, digunakan untuk mengukur banyaknya air yang digunakan.

3. Piknometer.

4. Kerucut terpancung

5. Batang perojok

6. Pan aluminium

7. Pelat kaca

8. Cawan

9. Oven yang dilengkapi pengatur suhu.

10. Density spoon

11. Timbangan

12. Tabung silinder

13. Jangka sorong, digunakan untuk mengukur semua dimensi benda uji.

14. Kuas

15. Ember plastic

16. Cetakan kubus dengan ukuran $(5 \times 5 \times 5)$ $\mathrm{cm}$

17. Sendok semen

18. Universal Testing Machine (Tokyo Testing Machine Inc.) kapasitas $1000 \mathrm{kN}$

19. Ayakan, Lolos saringan No. 200 (komposisi agregat halus sesuai dengan standar)

20. Kain basah.

\subsection{Bahan}

Bahan yang digunakan dalam penelitian ini adalah :

1. Semen Portland Tipe I merek Semen Baturaja

2. Agregat Halus Sungai Musi Sekayu

3. Agregat Sungai Musi Gandus Palembang

4. Air PDAM

Sebelum membeli bahan-bahan tersebut, sebaiknya diperkirakan terlebih dahulu berapa jumlah yang dibutuhkan. Untuk pasir : Sebaiknya jumlah pasir dilebihkan, agar pemeriksaan agregat tidak terulang lagi, karena mengingat karakteristik agregat tidak akan sama untuk tiap pembelian. Semen sebaiknya dibeli, pada waktu mendekat hari pencetakan, karena penyimpanan semen yang terlalu lama akan mengurangi mutu, jika penyimpanan yang kurang tepat dapat menyebabkan semen mengeras dan terjadi penggumpalan.

\subsection{Prosedur Pembuatan Bahan Uji Mortar}

1. Pencampuran

Bahan-bahan seperti semen dan pasir ditimbang dengan perbandingan $1: 2,75$.

2. Pengadonan

Setelah semua bahan dicampur maka bahan tersebut diberi air pada bagian tengah adonan serta dibiarkan selama 60 detik agar campuran saling mengikat lalu campuran tersebut diaduk sampai campuran benarbenar homogen.

3. Pencetakan

Setelah pengadonan selesai dilakukan pencetakan dengan memasukkan pasta mortar kedalam cetakan kubus yang telah diolesi Vaseline terlebih dahulu dengan cara :

- Di masukkan pasta setinggi 1/3 tinggi cetakan, kemudian campuran dirojok paling sedikit 25 kali untuk menjamin kepadatan susunan campuran.

- Di masukkan kembali 1/3 pasta mortar ke dalam cetakan kemudian dirojok kembali.

- Di masukkan kembali pasta mortar kedalam cetakan sampai penuh kemudian dirojok kembali.

- Diratakan permukaan cetakan lalu ditutup dengan kain basah selama \pm 24 jam.

\subsection{Perencanaan Campuran dan Prosedur Uji Kualitas Mortar}

2.7.1. Perencanaan Campuran Mortar Campuran mortar berpedoman pada

Standard ASTM C109-93, yaitu:

- Cetakan kubus 5 x 5 x $5 \mathrm{~cm}$

- Sampel dapat dibuat dengan perincian bahan adalah: 


\begin{tabular}{|l|c|}
\hline & 3 sampel \\
\hline Semen & 250 gram \\
\hline Pasir & 687,5 gram \\
\hline Air & $121 \mathrm{ml}$ \\
\hline
\end{tabular}

\subsubsection{Prosedur Pengujian Kekuatan Tekanan Mortar \\ Pengujian kuat tekanan mortar} dilakukan untuk mengetahui kuat tekan hancur dari benda uji tersebut. Benda uji yng dipakai adalah kubus dengan ukuran sisinya ( 5 x 5 x 5 ) $\mathrm{cm}$. pengujian kuat tekanan mortar dilakukan saat mortar berumur 7, 14, 21 dan 28 hari. Jumlah mortar yang di uji yaitu terdiri dari 3 buah sampel untuk masing-masing campuran.

Prosedur kerja untuk pengujian kuat tekan pada benda uji mortar, antara lain :

1. Dikeluarkan benda uji setelah mencapai umur yang direncanakan dari bak perendaman lalu dikeringkan dengan lap dan dibiarkan selama 24 jam.

2. Benda uji diletakkan pada mesin penekan.

3. Diberikan beban tekan secara perlahanlahan pada benda uji dengan cara mengoperasikan tuas pompa sehingga benda uji runtuh dan hancur.

4. Pada saat jarum penunjuk skala beban tidak lagi bergerak atau bertambah maka skala yang ditunjukkan oleh jarum tersebut dicatat sebagai beban maksimum yang dapat dipikul oleh benda uji tersebut.

5. Prosedur ini diulang untuk sampel benda uji kuat tekan yang lain.

Kuat tekan dapat diperoleh dengan rumus, sebagai berikut :

$$
f^{I}=\frac{F}{A}
$$

Dengan :

$\mathrm{Fc}^{\mathrm{I}}=$ Kuat tekan benda uji $\left(\mathrm{kg} / \mathrm{cm}^{2}\right)$

$\mathrm{F} \quad=$ Beban tekan maksimum $(\mathrm{kg})$

A $=$ Luas bidang permukaan $\left(\mathrm{cm}^{2}\right)$

IV. ANALISIS DAN PEMBAHASAN

4.1. Pengujian Bahan Agregat Halus
Material yang digunakan dalam penelitian ini yaitu agregat halus (pasir) dari sungai musi sekayu Musi Banyuasin dan agregat halus sungai musi gandus Palembang. Pengujian agregat ini mengacu pada SNI (Standar Nasional Indonesia). Pengujian ini dilakukan di Lab. Struktur dan Bahan Program Studi Teknik Sipil Fakultas Teknik Universitas Palembang, dan Lab. Program Studi Teknik Sipil Politeknik Negeri Sriwijaya.

Tabel. 4.1. Hasil Pengujian Bahan Agregat Halus

\begin{tabular}{|c|c|c|c|c|c|}
\hline \multirow{2}{*}{ No. } & \multirow{2}{*}{ Pengujian } & \multirow{2}{*}{ Parameter } & \multirow{2}{*}{ Syarat } & \multicolumn{2}{|c|}{ Hasil } \\
\hline & & & & $\begin{array}{c}\text { Pasir } \\
\text { Sekayu }\end{array}$ & $\begin{array}{c}\text { Pasir } \\
\text { Palembang }\end{array}$ \\
\hline 1 & $\begin{array}{l}\text { Kadar } \\
\text { lumpur }\end{array}$ & & $\leq 5 \%$ & 0,58 & 1,27 \\
\hline 2 & $\begin{array}{l}\text { Berat jenis } \\
\text { dan } \\
\text { penyerapan } \\
\text { agregat }\end{array}$ & $\begin{array}{l}\text { Berat jenis } \\
\text { kering } \\
\text { permukaan }\end{array}$ & $2,5-2,7$ & 2,95 & 2,55 \\
\hline 3 & $\begin{array}{l}\text { Berat } \\
\text { volume } \\
\text { agregat }\end{array}$ & $\begin{array}{l}\text { Berat } \\
\text { volume } \\
\text { kondisi } \\
\text { padat }\end{array}$ & $\begin{array}{c}1.500- \\
1.800 \\
\left(\mathrm{Gr} / \mathrm{cm}^{3}\right)\end{array}$ & 1.505 & 1.557 \\
\hline 4 & $\begin{array}{l}\text { Analisa } \\
\text { saringan }\end{array}$ & $\begin{array}{l}\text { Nilai } \\
\text { modulus } \\
\text { halus } \\
\text { butiran }\end{array}$ & $1,5-3,8$ & 3,20 & 2,92 \\
\hline
\end{tabular}

Pasir sungai musi Sekayu dan pasir sungai musi Palembang termasuk dalam agregat normal karena masuk dalam spesifikasi berat jenisnya $2,5-2,7 \mathrm{gr} / \mathrm{cm}^{3}$. Begitu juga modulus kehalusan masuk spesifikasi yang diijinkan $1,5-3,8$

\subsection{Rancang Campuran Mortar}

Komposisi campuran mortar untuk benda uji dibuat dengan standar ASTM C10993 perbandingan băhah-bahan kering yang digunakan adalah 1 bagian berat semen berbanding 2 bagian berat pasir, 1 bagian berat semen berbanding 3 bagian berat pasir, 1 bagian berat semen berbanding 4 bagian berat pasir, dan faktor air semen adalah 0,484 untuk semua jenis semen portland.

\subsection{Hasil Pengujian Kuat Tekan Mortar}

Data hasil pengujian kekuatan tekan mortar sesuai dengan hasil penelitian yang dilakukan, tertera pada tabel berikut : 
Tabel 4.2. Rekapitulasi kuat tekan mortar

\begin{tabular}{|c|c|c|c|c|c|c|c|c|}
\hline \multirow{8}{*}{$\begin{array}{c}\text { Kompo } \\
\text { sisi } \\
\text { Campu } \\
\text { ran }\end{array}$} & \multicolumn{6}{|c|}{ Kuat tekan rata-rata mortar } \\
\cline { 2 - 9 } & $\begin{array}{c}7 \\
\text { hari } \\
\text { hari }\end{array}$ & $\begin{array}{c}21 \\
\text { hari }\end{array}$ & $\begin{array}{c}28 \\
\text { hari }\end{array}$ & $\begin{array}{c}7 \\
\text { hari }\end{array}$ & $\begin{array}{c}14 \\
\text { hari }\end{array}$ & $\begin{array}{c}21 \\
\text { hari }\end{array}$ & $\begin{array}{c}28 \\
\text { hari }\end{array}$ \\
\hline $\begin{array}{c}\text { 1 PC : } \\
\text { 2 Pasir }\end{array}$ & 28,47 & 32,33 & 40,07 & 50,00 & 25,80 & 29,32 & 30,80 & 31,80 \\
\hline $\begin{array}{c}\text { 1 PC : } \\
\text { 3 Pasir }\end{array}$ & 33,33 & 38,00 & 47,60 & 56,00 & 30,67 & 34,87 & 36,60 & 40,20 \\
\hline $\begin{array}{c}\text { 1 PC: } \\
\text { 4 Pasir }\end{array}$ & 30,47 & 34,80 & 42,67 & 53,33 & 28,40 & 31,73 & 34,87 & 38,73 \\
\hline
\end{tabular}

Grafik 4.1. Rekapitulasi kuat tekan mortar

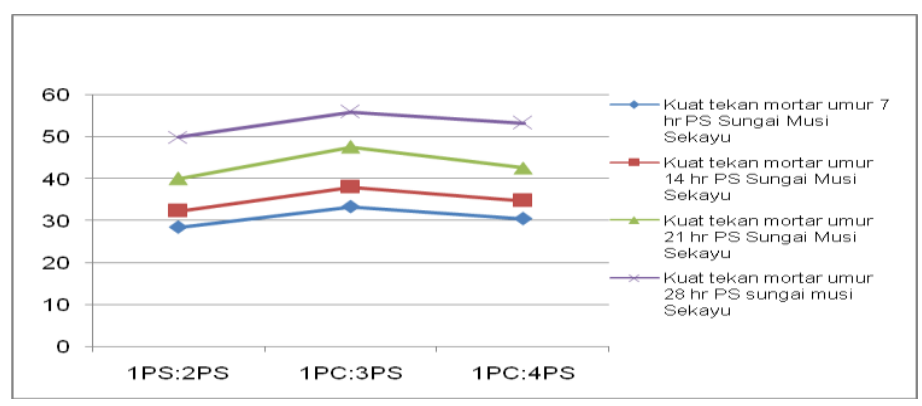

\section{PENUTUP}

\subsection{Kesimpulan}

Dari hasil penelitian dan pengujian kuat tekan mortar dengan menggunakan agregat halus sungai musi Sekayu dan agregat sungai musi gandus Palembang dapat disimpulkan bahwa :

1. Nilai kuat tekan mortar dengan komposis campuran 1 PC : 2 Pasir sungai musi Sekayu pada umur 28 hari kuat tekan ratarata mortar $50,00 \mathrm{~kg} / \mathrm{cm}^{2}$, sedangkan komposis campuran 1 PC : 2 Pasir sungai musi gandus Palembang pada umur 28 hari kuat tekan rata-rata mortar $31,80 \mathrm{~kg} / \mathrm{cm}^{2}$

2. Nilai kuat tekan mortar dengan komposis campuran 1 PC : 3 Pasir sungai musi Sekayu pada umur 28 hari kuat tekan ratarata mortar $56,00 \mathrm{~kg} / \mathrm{cm}^{2}$, sedangkan komposis campuran 1 PC : 3 Pasir sungai musi gandus Palembang pada umur 28 hari kuat tekan rata-rata mortar $40,20 \mathrm{~kg} / \mathrm{cm}^{2}$

3. Nilai kuat tekan mortar dengan komposis campuran 1 PC : 4 Pasir sungai musi Sekayu pada umur 28 hari kuat tekan ratarata mortar $53,33 \mathrm{~kg} / \mathrm{cm}^{2}$, sedangkan komposis campuran 1 PC : 4 Pasir sungai musi gandus Palembang pada umur 28 hari kuat tekan rata-rata mortar $38,73 \mathrm{~kg} / \mathrm{cm}^{2}$

4. Nilai kuat tekan optimum mortar terdapat pada komposisi campuran 1 Pc : 3 Pasir sungai musi Sekayu, pada umur 28 hari kuat tekan rata-rata mortar $56,00 \mathrm{~kg} / \mathrm{cm}^{2}$.

\subsection{Saran}

Diharapkan dapat dilakukan penelitian lanjutan dengan menggunakan agregat halus sungai musi Sekayu dan agregat sungai musi gandus Palembang dengan komposisi campuran yang berbeda dan variasi lama rendaman (perawatan).

\section{DAFTAR PUSTAKA}

[1] Tjokrodimuljo, 2007:79, Teknologi Bahan Konstruksi, Buku Ajar. Jurusan Teknik Sipil, Universitas Atma Jaya. Yogyakarta.

[2] Tjokrodimuljo, 2007:80, Teknologi Bahan Konstruksi, Buku Ajar. Jurusan Teknik Sipil, Universitas Atma Jaya. Yogyakarta.

[3] SNI 03 - 2834-2002b "Tata Cara Pembuatan Campuran Beton Normal" Badan Standarisasi nasional (BSN) ICS 91.100.30

[4] SNI 03-1971-1990 Metode Pengujian Kadar Air Agregat, Badan Standarisasi Nasional

[5] SNI 03-1970-2008 Cara Uji Berat Jenis dan Penyerapan Air Agregat Halus, Badan Standarisasi Nasional

[6] SNI 03-1974-1990 Metode Pengujian Analisa Saringan Agregat Halus dan Kasar, Badan Standarisasi Nasional

[7] SNI 1969:2008 Cara Uji Berat Jenis dan Penyerapan Air Agregat Kasar, Badan Standarisasi Nasional

[8] Tjokrodimuljo, 1996, Teknologi Bahan Konstruksi, Buku Ajar. Jurusan Teknik Sipil, Universitas Atma Jaya. Yogyakarta. 